\title{
Predykcja ciśnień porowych w otworach wiertniczych przewiercających dolnopaleozoiczne formacje łupkowe basenu bałtyckiego - północna Polska
}

\begin{abstract}
W niniejszej pracy przedstawiono wyniki analizy ciśnienia porowego przy wykorzystaniu powszechnie stosowanych w przemyśle naftowym metod predykcji ciśnienia porowego, dostępnych na platformie specjalistycznego oprogramowania. Analizę ciśnień porowych przeprowadzono w niemal pełnym interwale czterech otworów wiertniczych przewiercających perspektywiczny interwał łupków dolnego paleozoiku zdeponowanych w południowej części basenu bałtyckiego. Wyniki analizy pozwoliły na wskazanie poziomów o podniesionym ciśnieniu porowym, których przewiercanie może wiązać się z komplikacjami wiertniczymi, a nawet prowadzić do utraty stabilności ściany odwiertu.
\end{abstract}

Słowa kluczowe: ciśnienie porowe, niekonwencjonalne formacje łupkowe, strefy podniesionego ciśnienia porowego, naprężenia efektywne, model geomechaniczny.

\section{Pore pressure prediction in the lower Paleozoic shale formation in the Baltic Basin, North Poland}

This paper presents the results of the pore pressure prediction conducted in almost the entire profile, of four boreholes, drilled through perspective intervals of the lower Paleozoic shales deposited in the southern part of the Baltic Basin. The Pore pressure prediction, was carried out with the use of Eaton and Bowers methods, which are commonly used methods in the oil and gas industry. The results of the analysis allowed to identify overpressure zones, which may lead to drilling complications and even wellbore instability issues.

Key words: Pore pressure, unconventional shale formation, overpressure zones, effective stress, geomechanical modeling.

\section{Wprowadzenie}

Ciśnienie porowe i stabilność ściany otworu odwiertu stanowią niekiedy poważne wyzwanie podczas wiercenia otworów wiertniczych, zwłaszcza w strefach spodziewanego występowania podwyższonego ciśnienia porowego. Brak predykcji ciśnienia porowego wprowadza element niepewności przy doborze gęstości płynu wiertniczego, mogący prowadzić do wielu niepożądanych komplikacji podczas wiercenia, takich jak erupcje wiertnicze (ang. blowouts), niekontrolowany wypływ płynów złożowych (ang. kicks), wymycia ściany odwiertu (ang. washouts), powstanie stref znisz- czenia w mechanizmie ścinania i rozciągania (ang. breakouts and drilling induced fractures) czy zakleszczenie rury wiertniczej (ang. stuck pipe). Pojawienie się wspomnianych komplikacji wiertniczych najczęściej wpływa na wydłużenie czasu operacyjnego, podniesienie kosztów wiercenia, a niejednokrotnie wymagało opuszczenia otworu wiertniczego. Wymienionych wyżej komplikacji można uniknąć bądź mocno je ograniczyć poprzez wprowadzenie elementu rzetelnej analizy warunków wiercenia, w tym analizy ciśnień porowych.

\section{Ciśnienie porowe i mechanizmy powstania stref nadciśnienia}

Ciśnienie porowe to ciśnienie wywierane przez płyn wypełniający przestrzeń porową na danej głębokości, przeciw- działające wartości naprężeń podstawowych [12] (rysunek 1). $\mathrm{Z}$ praktycznego punktu widzenia ciśnienie porowe to najważ- 


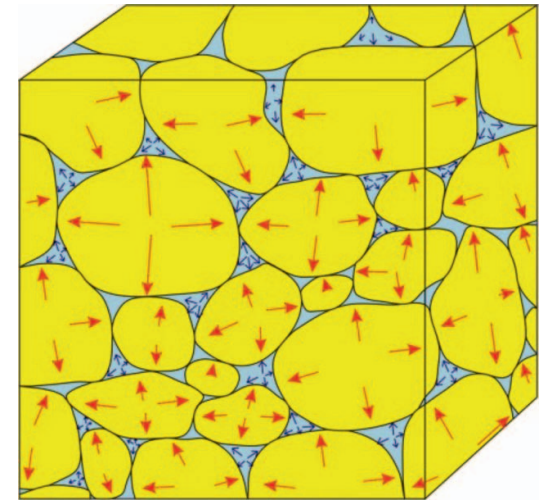

Rys. 1. Naprężenie całkowite i naprężenie efektywne, będące wynikiem działania ciśnienia porowego w przestrzeni porowej

niejszy parametr geomechaniczny, ponieważ jego znajomość wpływa na efektywne i bezawaryjne wiercenie.

W skałach o dużej przepuszczalności, wykazujących dobrą łączność hydrauliczną z otaczającymi formacjami skalnymi, ciśnienie porowe ulega wyrównaniu i przyjmuje się, że jego wartość jest równa ciśnieniu hydrostatycznemu $\left(P_{h}\right)$ wywieranemu przez słup wody na danej głębokości. Wartość ciśnienia porowego na tej głębokości może być wówczas obliczona według wzoru (1):

$$
P_{h}=g \cdot p \cdot z
$$

gdzie:

$g$ - stała przyśpieszenia ziemskiego,

$\rho$ - gęstość płynu porowego,

$z$ - głębokość.
Nie zawsze jednak mamy do czynienia ze skałami o dobrej przepuszczalności, a najlepszym na to przykładem są formacje łupkowe, którym w ostatnich latach przypisuje się wysoki potencjał węglowodorowy. W skałach łupkowych będących przedmiotem niniejszej pracy często spotyka się interwały o anomalnie podwyższonym ciśnieniu porowym [7].

Najlepiej opisanym mechanizmem prowadzącym do powstania stref podwyższonego ciśnienia porowego jest model kompakcyjny (ang. undercompaction). Mechanizm ten zakłada, że na danej głębokości postępująca sedymentacja prowadzi do podwyższenia ciśnienia nadkładu, a w konsekwencji do kompakcji osadów i towarzyszącej jej redukcji porowatości. W przypadku osadów o bardzo niskiej przepuszczalności ucieczka płynów znajdujących się w przestrzeni porowej, ze względu na słabe warunki przepływu, nie nadąża za spadkiem porowatości, a rosnące ciśnienie nadkładu skał powodujące kompakcję jest bezpośrednią przyczyną powstania podwyższonego ciśnienia. W efekcie na danej głębokości pogrążenia skała zachowuje podwyższoną porowatość $\mathrm{w}$ porównaniu z osadami podlegającymi kompakcji, pozostając $w$ równowadze hydraulicznej z otaczającymi osadami [17].

Innymi znanymi mechanizmami odpowiedzialnymi za powstanie stref anomalnego ciśnienia porowego w ośrodku skalnym jest nacisk tektoniczny, przemiany kerogenu i kompakcja chemiczna [11]. Dwa ostatnie związane są bezpośrednio ze zmianą objętości powstających związków węglowodorowych czy podlegających przemianom minerałów.

\section{Metody szacowania ciśnienia porowego w osadach o niskiej przepuszczalności}

Pomiar ciśnienia porowego w skałach o niskiej przepuszczalności z uwagi na bardzo wydłużony czas oczekiwania przypływu medium złożowego nie jest w praktyce wykonywany, a wartość ciśnienia porowego szacuje się za pomocą dostępnych modeli obliczeniowych. Metody szacowania ciśnienia porowego wykorzystują zaobserwowaną zależność między spadkiem porowatości w formacji skalnej i wzrostem ciśnienia porowego wraz z głębokością, co wynika z założeń modelu kompakcyjnego.

Głównym założeniem większości metod szacowania ciśnienia porowego jest redukcyjny wpływ efektywnego naprężenia pionowego (generowanego przez ciężar skał nadkładu), najczęściej obliczanego jako różnica ciśnienia litostatycznego i ciśnienia porowego (rysunek 2), na porowatość osadów.

Powyższe prowadzi do wymiernego związku pomiędzy efektywnym naprężeniem pionowym i porowatością - lub inną cechą ośrodka skalnego zależną od porowatości, np. opornością czy prędkością fali sprężystej $[15,16]$.

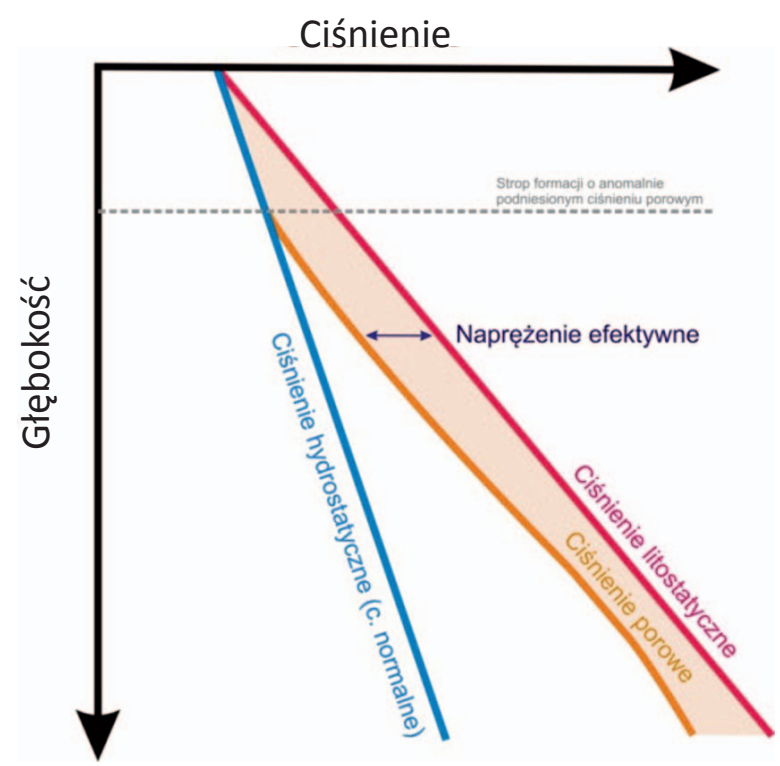

Rys. 2. Rozkład ciśnienia porowego, litostatycznego i pionowego naprężenia efektywnego w głębokości $\mathrm{w}$ formacji o anomalnie podniesionym ciśnieniu porowym 
Większość metod szacowania ciśnienia porowego przy zastosowaniu prędkości fali podłużnej czy oporności wykorzystuje metody Eatona, Bowersa i ich modyfikacje [9], a wy- bór wykorzystywanej metody w znacznej mierze zależeć powinien od mechanizmu powstawania stref o podwyższonym ciśnieniu porowym $\mathrm{w}$ rejonie zainteresowania.

\section{Szacowanie ciśnienia porowego na podstawie oporności}

Zarejestrowane wyniki profilowania opornościowego mogą być wykorzystane do szacowania ciśnienia porowego poprzez posłużenie się zależnością matematyczną zaproponowaną przez Eatona już w 1972 roku [5]:

$$
P_{p g}=O B G-\left(O B G-P_{n g}\right)\left(\frac{R}{R_{n}}\right)^{n}
$$

gdzie:

$P_{p g}-$ gradient ciśnienia porowego w formacji,

$O B G$ - gradient ciśnienia litostatycznego (ang. overburden gradient),

$P_{n g}$ - gradient ciśnienia hydrostatycznego (ang. normal pressure gradient) (około 1,03 MPa/km = 10,3 bar/ km w za- leżności od zasolenia płynu wypełniającego przestrzeń porową),

$R$ - oporność skały łupkowej określona na podstawie danych geofizyki wiertniczej,

$R_{n}$ - oporność skał łupkowych z hydrostatycznym ciśnieniem płynów porowych,

$n$ - wykładnik zawierający się w przedziale od 0,6 do $1,5[13]$.

Opornościowa metoda Eatona może być stosowana do szacowania ciśnienia porowego, szczególnie w młodych basenach sedymentacyjnych, o ile normalna oporność skał jest poprawnie zmierzona $[9,15]$.

\section{Szacowanie ciśnienia porowego na podstawie prędkości i czasu interwałowego}

Metoda Eatona jest powszechnie stosowaną w przemyśle naftowym metodą szacowania ciśnienia porowego wykorzystującą prędkość fali sejsmicznej do obliczania pionowego naprężenia efektywnego $\sigma_{v}$. W 1975 roku Eaton zaproponował następujący związek empiryczny pozwalający na szacowanie gradientu ciśnienia porowego na podstawie czasu interwałowego fali akustycznej [16]:

$$
P_{p g}=O B G-\left(O B G-P_{n g}\right)\left(\Delta t_{n} / \Delta t\right)^{3}
$$

gdzie:

$P_{p g}-$ gradient ciśnienia porowego, równy iloczynowi ciśnienia porowego w formacji na danej głębokości,

$O B G$ - gradient ciśnienia litostatycznego,

$P_{n g}-$ gradient ciśnienia hydrostatycznego,

$\Delta t_{n}$ - czas interwałowy fali propagującej w skałach o niskiej

przepuszczalności przy ciśnieniu hydrostatycznym,

$\Delta t$ - czas interwałowy zarejestrowany w otworze wiertniczym.
Ciśnienie porowe może być następnie szacowane przy wykorzystaniu wcześniej obliczonego całkowitego naprężenia pionowego.

W celu użycia metody Eatona wymagane jest określenie odchylenia prędkości rzeczywistej od prędkości, z jaką propagowałaby fala sprężysta w ośrodku, w którym uformowało się normalne ciśnienie porowe.

Metoda Bowersa opiera się na empirycznie założonym związku między efektywnym naprężeniem pionowym a prędkością fali poprzecznej $v$ propagującej w badanym ośrodku skalnym:

$$
v=v_{0}+A \sigma^{B}
$$

gdzie: $v_{o}$ - prędkość propagacji fali poprzecznej w nieskonsolidowanych osadach nasyconych płynem $(\sim 1500 \mathrm{~m} / \mathrm{s})$, a parametry $A$ i $B$ opisują zmienność prędkości ze wzrostem naprężenia efektywnego $[4,10]$.

\section{Szacowanie ciśnienia porowego w dolnopaleozoicznych formacjach łupkowych basenu bałtyckiego}

Analiza ciśnień porowych została przeprowadzona w oprogramowaniu Techlog (Schlumberger) dla czterech otworów wiertniczych: L-1, O-2, O-3 i O-4, przewiercających dolnopaleozoiczne formacje łupkowe zdeponowane w południowej części basenu bałtyckiego. Predykcja ciśnień porowych w kolejnych formacjach litostratygraficznych bazowała na powszechnie stosowanych metodach opierających się na da- nych geofizyki otworowej, a konkretnie na profilowaniu akustycznym (czas interwałowy, ang. slowness) i profilowaniu oporności elektrycznej (ang. resistivity) (rysunek 3).

Wśród metod wykorzystanych do predykcji ciśnienia porowego w poszczególnych interwałach znalazły się metoda Eatona i metoda Bowersa, wykorzystujące wspomniane typy danych geofizyki wiertniczej. 


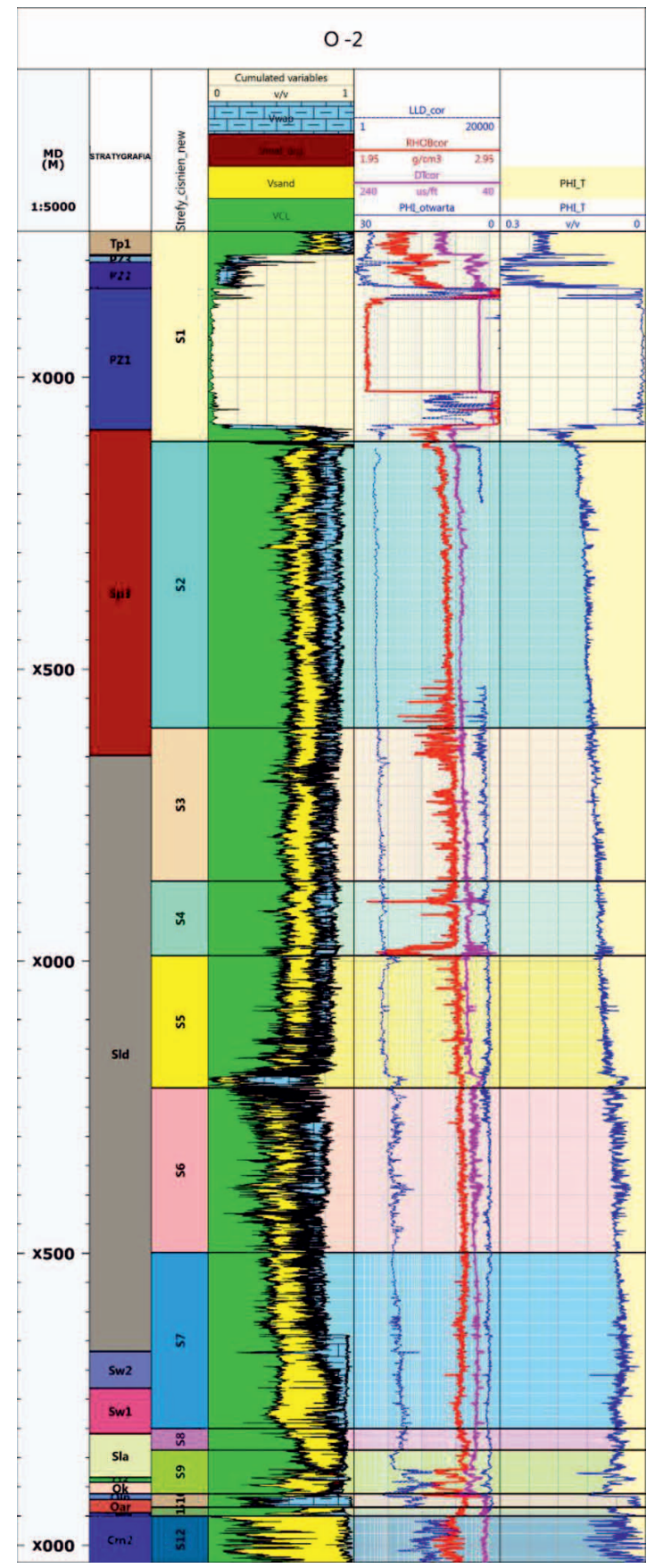

Rys. 3. Zestawienie krzywych profilowania geofizyki otworowej - od lewej: profilowanie oporności elektrycznej (LLD_cor), gęstość właściwa (RHOB_cor), czas interwałowy fali podłużnej DT, szacowana porowatość otwarta (PHI otwarta), szacowana porowatość całkowita (PHI_T)

Uzyskane krzywe ciśnień porowych były następnie kalibrowane punktowym zbiorem ciśnień porowych szacowanych na podstawie parametrów wiercenia $\mathrm{z}$ zastosowaniem tzw. metody D-exponent. Metoda ta wykorzystuje związek między parametrami wiercenia, tj. postępem wiercenia ROP (ang. rate of penetration), naciskiem na świder WOB (ang. weight on bit), liczbą obrotów świdra na minutę RPM (ang. rotation per minute), a ciśnieniem porowym zwiercanej formacji skalnej [3].

\section{Szacowanie ciśnień porowych w wydzielonych interwatach}

Dla uzyskania lepszego dopasowania obliczonych krzywych ciśnień porowych z punktami kalibracyjnymi poddany analizie profil podzielono na 12 interwałów: S1-S12.

Podział na poszczególne interwały odbywał się na podstawie zmienności zachowania się oszacowanego metodą D-exponent ciśnienia porowego. Obserwowane gwałtowne wzrosty czy spadki jego wartości oraz towarzyszące zmiany w trendzie krzywych geofizyki wiertniczej (czas interwałowy, oporność) najczęściej związane były ze zmianą litologii w profilu, stanowiąc odbicie zmian warunków hydraulicznych przepływu medium w przestrzeni porowej analizowanego ośrodka skalnego.

Przy analizie ciśnień porowych za otwór modelowy posłużył otwór wiertniczy O-2, w przypadku którego dysponowano największą liczbą punktów kalibracyjnych (punkty kalibracyjne oszacowane metodą $D$-exponent były dostępne w niemal pełnym profilu otworu). Dla otworu modelowego wybrano metodę szacowania ciśnienia porowego dla kolejno rozpatrywanych interwałów S1-S12 i dobrano parametry dopasowania odpowiadające wykorzystanej metodzie, tj. współczynniki dopasowania A i B Bowersa oraz współczynnik i eksponent Eatona, na takim poziomie, by uzyskać jak najlepszą zgodność obliczonych krzywych ciśnień porowych z punktami kalibracyjnymi.

W efekcie otrzymano krzywą ciśnień w pełnym profilu odwiertu O-2 oraz ustalone parametry dopasowania danej metody szacowania ciśnień porowych $\mathrm{w}$ danym interwale. Następnie wydzielono analogiczne interwały w pozostałych otworach wiertniczych, cechujące się podobną zmiennością krzywych geofizyki wiertniczej. W wydzielonych interwałach w pozostałych otworach zastosowano metodę wybraną dla odpowiadającego interwału w otworze modelowym z określonymi dla otworu O-2 współczynnikami dopasowania.

W efekcie końcowym uzyskano profile ciśnień porowych w czterech analizowanych otworach wiertniczych: L-1, O-2, O-3 i O-4 (rysunek 4).

W profilu czterech analizowanych odwiertów, w górnej jego części, obejmującej w części stropowej zakres od osadów wieku kredowego (wydzielona strefa S1) do dolnej części osadów ludlowu (Sld), panuje ciśnienie hydrostatyczne o gradiencie około $0,107 \div 0,108 \mathrm{bar} / \mathrm{m}$.

W poziomach leżących poniżej - począwszy od wydzielonego poziomu S7, obejmującego spągową część utworów łupkowych ludlowu (Sld), osady wenloku (Sw) po osady występujące do końca analizowanego profilu - obserwujemy występowanie powtarzalnych we wszystkich analizowanych otworach wiertniczych wyraźnych stref o anomalnie podniesionym ciśnieniu porowym. W interwałach S7 i S8 ciśnienie jest nie- 


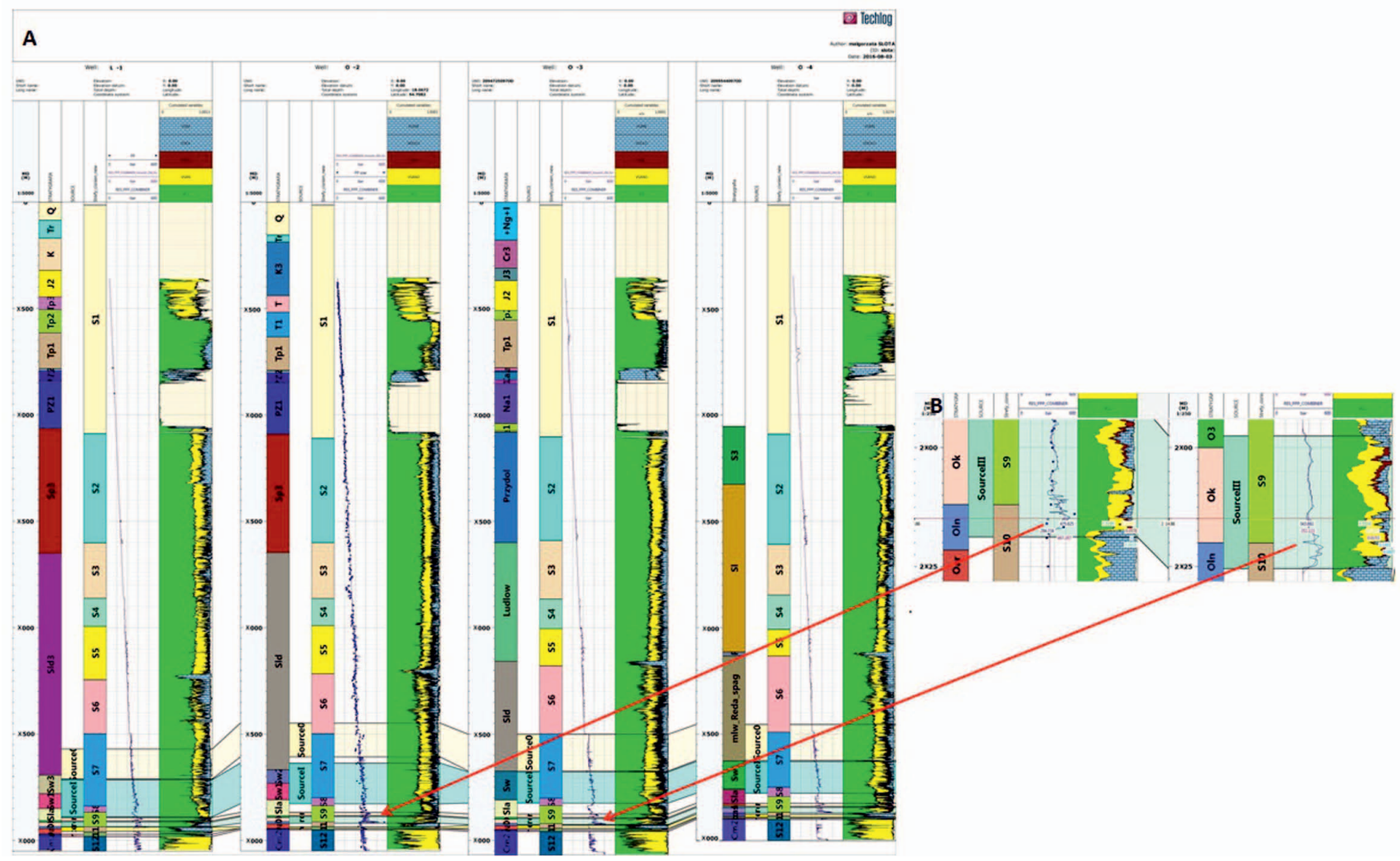

Rys. 4. Ilustracja przedstawiająca obliczone krzywe ciśnienia porowego RES PPP COMBINER SMOOTH_2M_FIN dla odwiertów L-1, O-2, O-3 i O4 wraz z naniesionymi punktami kalibracyjnymi PP_szac, wydzielonymi interwałami S1-S12 i profilem litologicznym

znacznie podniesione w stosunku do ciśnienia hydrostatycznego i jego gradient waha się w zakresie $0,109 \div 0,115 \mathrm{bar} / \mathrm{m}$.

Z pierwszą strefą o wyraźnie podniesionym ciśnieniu mamy do czynienia w przyspągowej części landoweru (Sla) w środkowej części interwału S9. Na omawianym poziomie obserwowalne są dwie strefy podwyższonego ciśnienia, z czego jedna z gradientem ciśnień w zakresie $0,135 \div 0,139 \mathrm{bar} / \mathrm{m}$, a druga, niżej leżąca, $\mathrm{z}$ gradientami w zakresie $0,118 \div 0,126 \mathrm{bar} / \mathrm{m}$.

Dwie kolejne strefy wykształcone zostały w osadach karadoku (Ok), w których panują gradienty ciśnienia porowego na poziomie $0,126 \div 0,131 \mathrm{bar} / \mathrm{m}$ w strefie wyżej leżącej oraz $0,126 \div 0,135 \mathrm{bar} / \mathrm{m}$ w strefie leżącej poniżej.

Następnie w utworach lanwirnu (Oln) zaobserwowano strefę ciśnień porowych o najbardziej podniesionych w całym profilu wartościach. Gradienty ciśnień w omawianej strefie osiągają wartości od $0,154 \mathrm{bar} / \mathrm{m}$ w otworze O-4 do nawet $0,161 \mathrm{bar} / \mathrm{m} \mathrm{w}$ modelowym otworze O-2 (rysunek 4).

Ostatnie wyróżnione strefy, stwierdzone w otworach L-1 i O-2, występują w osadach górnego kambru (Cm1), przy czym wyżej leżąca charakteryzuje się niższymi gradientami ciśnień, w zakresie $0,122 \div 0,129 \mathrm{bar} / \mathrm{m}$, a niżej leżąca - gradientami nieco wyższymi, od $0,124 \mathrm{bar} / \mathrm{m}$ do $0,130 \mathrm{bar} / \mathrm{m}$. $\mathrm{W}$ pozostałych otworach wiertniczych z uwagi na brak da- nych geofizyki wiertniczej w poziomie $\mathrm{Cm} 1$ analiza ciśnień nie była możliwa. Oszacowane zakresy gradientów ciśnień porowych dla omawianych wydzielonych stref podniesionego ciśnienia porowego zostały zebrane w tablicy 1 .

Tablica 1. Zestawienie ciśnień porowych w zaobserwowanych strefach podniesionego ciśnienia porowego

\begin{tabular}{|c|c|c|c|c|}
\hline Nazwa & L-1 & $\mathrm{O}-2$ & O-3 & $\mathrm{O}-4$ \\
\hline $\begin{array}{l}\text { Strefa } \\
\text { (poziom strat.) }\end{array}$ & \multicolumn{4}{|c|}{$\begin{array}{l}\text { Szacowane ciśnienie porowe [bar]/ } \\
\text { gradient }[\mathrm{bar} / \mathrm{m}]\end{array}$} \\
\hline S9 (Sla) & 0,139 & 0,139 & 0,139 & 0,135 \\
\hline S9 (Sla) & 0,125 & 0,126 & 0,125 & 0,118 \\
\hline S9 (Ok) & 0,130 & 0,130 & 0,131 & 0,126 \\
\hline S9 (Ok) & 0,132 & 0,135 & 0,134 & 0,126 \\
\hline $\mathrm{S} 10(\mathrm{Oln})$ & 0,155 & 0,161 & 0,157 & 0,154 \\
\hline $\mathrm{S} 11(\mathrm{Cm} 1)$ & 0,129 & 0,122 & - & - \\
\hline $\mathrm{S} 11(\mathrm{Cm} 1)$ & 0,130 & 0,124 & - & - \\
\hline
\end{tabular}

Występowaniu wszystkich opisanych stref o uformowanym anomalnie wysokim ciśnieniu porowym towarzyszy zwiększenie udziału piaskowców i w przypadku strefy występującej w przyspągowych utworach landoweru (Sla) - zwiększenie udziału węglanów. Jest bardzo prawdopodobne, że do 
uformowania się stref o wysokim ciśnieniu doszło właśnie w izolowanych w kierunku pionowym wkładkach piaskowcowych czy marglistych o wyższej porowatości. Uszczelnienie ukształtowanej strefy anomalnie podniesionych ciśnień porowych mogą stanowić utwory ilaste czy skały węglanowe o niskiej przepuszczalności (rysunek 4B). Dokładniejsze potwierdzenie stref uszczelniających wymaga dodatkowych badań, tj. analizy przepuszczalności czy badań petrograficznych.

Na podkreślenie zasługują również obserwowane w otworze O-4 niższe gradienty obliczonych ciśnień porowych. W pozostałych odwiertach w obrębie wszystkich analizowanych stref anomalnie podniesionego ciśnienia obserwuje się gradienty ciśnienia porowego na poziomie wyższym niż w odwiercie O-4. Prawdopodobną przyczyną może być istnienie poziomej zmienności litologicznej i/lub strukturalnej stanowiącej barierę dla przepływu płynów wypełniających przestrzeń porową - z czego ostatni wariant wydaje się bardzo prawdopodobny z uwagi na przestrzenne rozmieszczenie analizowanych odwiertów względem wyinterpretowanego systemu nieciągłości (rysunek 5).

Potwierdzenie istnienia bariery, o której mowa powyżej, wymaga dalszego rozpoznania, np. poprzez modelowanie facjalne czy reinterpretację strukturalną przy wykorzystaniu danych sejsmicznych.

\section{Przestrzenny model ciśnienia porowego łupków dolnopaleozoicznych}

Modelowanie 3D ciśnień porowych zrealizowane w niniejszej pracy wykonano dla paleozoicznej formacji łupkowej, która stratygraficznie obejmuje interwał od sylurskich mułowców wapnistych z Redy (ludlow) Sld, zalegających na głębokości ponad 2000 m (według miary wiertniczej), do mułowców środkowokambryjskich poziomu Paradoxides Paradoximus (Cm2pp), leżących na głębokości powyżej $3000 \mathrm{~m}$. W oprogramowaniu Petrel $^{\text {TM }}$ (Schlumberger) stworzono model, którego rozciągłość południkowa wynosi $11,77 \mathrm{~km}$, a równoleżnikowa $12,75 \mathrm{~km}$. Rozdzielczość horyzontalna modelu blokowego została zdefiniowana na $100 \mathrm{~m} \times 100 \mathrm{~m}$. Rozdzielczość pionowa modelu jest zmienna w zależności od poszczególnych wydzielonych stref i wynosiła od 23,5 m do 125,88 m. Całkowita liczba komórek w modelu blokowym wynosi około 680 tysięcy.
Model 3D ciśnienia porowego w analizowanym poziomie łupkowym został uzyskany przy wykorzystaniu opracowanych profili ciśnień porowych w otworach wiertniczych: L-1, O-2, O-3 i O-4, skalibrowanych danymi otrzymanymi na podstawie analizy parametrów wiercenia z otworów L-1 i O-2.

Zakresy zmienności modelowanego ciśnienia porowego oszacowano na podstawie statystycznej analizy danych otworowych, podczas której dokonano wyboru teoretycznego modelu wariogramu i wartości zasięgu strefy oddziaływania w kierunku pionowym i poziomym.

Wariogramy wykreślone dla kierunku pionowego dla poszczególnych otworów wiertniczych pozwoliły na określenie wartości zasięgu strefy oddziaływania w kierunku pionowym, które w przypadku kolejnych otworów wiertniczych

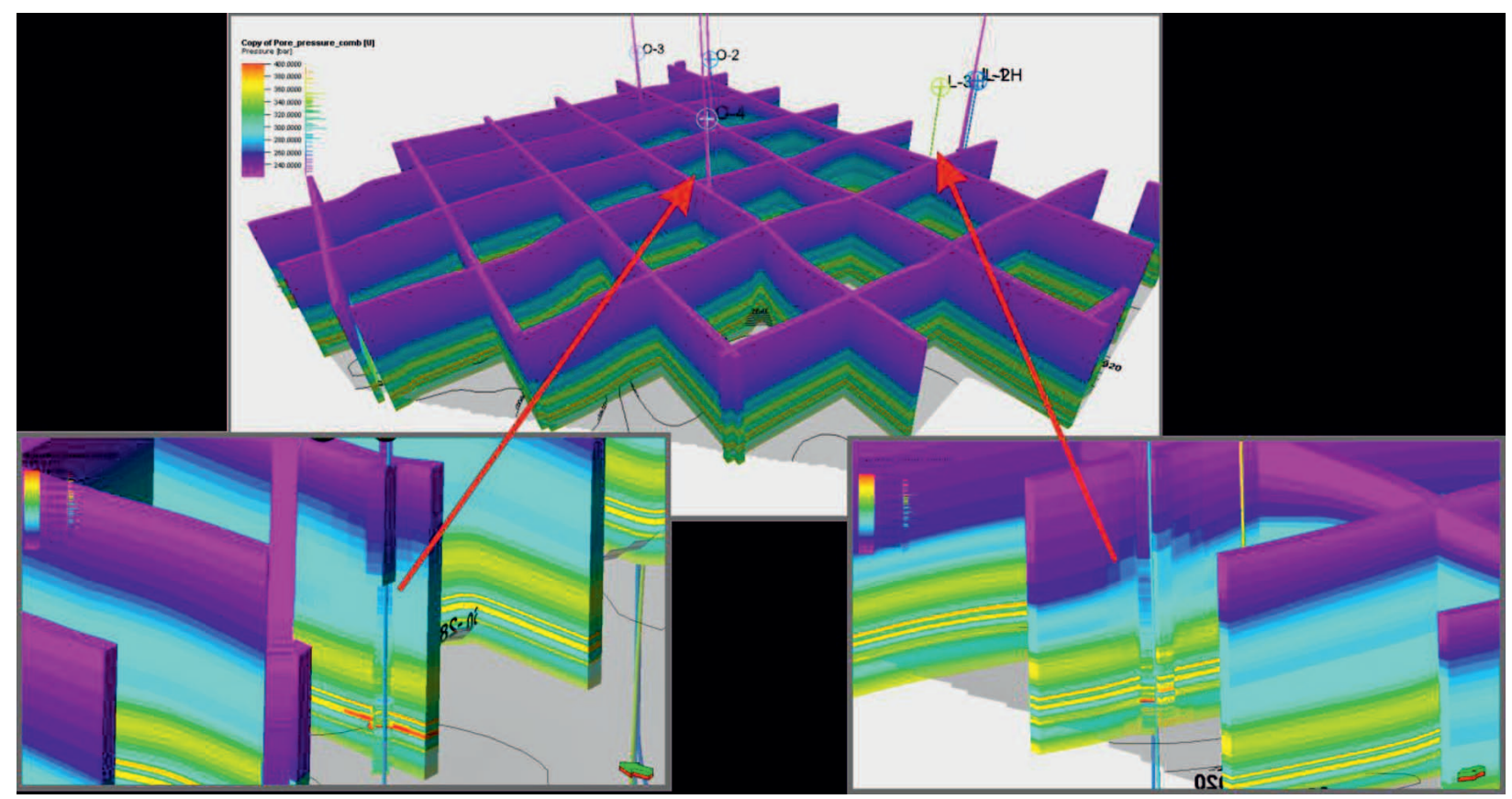

Rys. 5. Rozkład przestrzenny ciśnienia porowego na obszarze objętym zdjęciem sejsmicznym O-3D (w środku) oraz w otoczeniu otworów L-1 (z lewej) i O-2 (z prawej). W profilu obu tych otworów wiertniczych manifestuje się istnienie strefy oznaczonej kolorem czerwono-żółtym o podniesionym ciśnieniu porowym - o wartości $425 \div 475$ barów 
wynosiły: 13,0 m dla otworu L-1, 10,9 m dla O-2, 14,0 m dla O-3 i 13,5 m dla otworu O-4.

Parametry informujące o zmienności modelowanych ciśnień porowych $\mathrm{w}$ kierunku poziomym, a więc minimalny i maksymalny zakres oddziaływania w tym kierunku, zostały ustalone na podstawie analizy statystycznej semiwariogramu wykreślonego dla czterech otworów wiertniczych dla kierunku poziomego i zostały założone na poziomie odpowiednio: $3600 \mathrm{~m}$ w przypadku minimalnego i $6100 \mathrm{~m}$ dla maksymalnego.

Analiza statystyczna danych wejściowych w postaci opracowanych profili ciśnień porowych z czterech otworów wiertniczych pozwoliła na określenie parametrów sterujących sposobem interpolacji danych wejściowych w przestrzennej siatce modelu blokowego. Modelowanie przestrzenne poprzedzone było etapem arytmetycznego uśrednienia wysokorozdzielczych profili ciśnień porowych o rozdzielczości $0,1 \mathrm{~m}$ do rozdzielczości modelu blokowego w procesie upscalingu .

W efekcie modelowania uzyskano przestrzenny rozkład ciśnienia porowego w całym obiekcie O-3D (rysunek 5).

Wykonana dodatkowo mapa średnich wartości ciśnienia porowego w jednym z perspektywnych interwałów łupkowych manifestuje niższe wartości ciśnienia porowego $\mathrm{w}$ rejonie otworu wiertniczego O-4 i wyższe w porównaniu z tłem ciśnienia w otworach O-2 i O-3. Jak widać na rysunku 6 , może mieć to związek z izolacją o charakterze tektonicznym.

Uzyskane profile czy przestrzenny model ciśnień porowych może następnie być wykorzystywany do modelowania geomechanicznego 1D i 3D, stanowiąc podstawę do obliczenia podstawowych naprężeń efektywnych [6] (rysunek 7).

W związku z ograniczonym zakresem danych niosących informacje na temat zmienności ciśnień porowych w kierunku poziomym i tym samym słabą reprezentatyw- nością danych w kierunku poziomym w zasięgu konstruowanego modelu - należy się liczyć z niepewnością uzyskanego modelu ciśnienia porowego. W ramach ewentualnego kontynuowania tematyki na wybranym obiekcie O-3D wskazane wydaje się wykorzystanie danych sejsmicznych jako nośnika informacji o rozkładzie ciśnienia porowego $[2,8,14]$. Użycie tych danych ograniczyłoby niepewność rozkładu w kierunku poziomym i umożliwiłoby stwierdzenie obecności ewentualnych barier dla ciągłości zinterpretowanych w otworach wiertniczych stref o podniesionym ciśnieniu porowym.

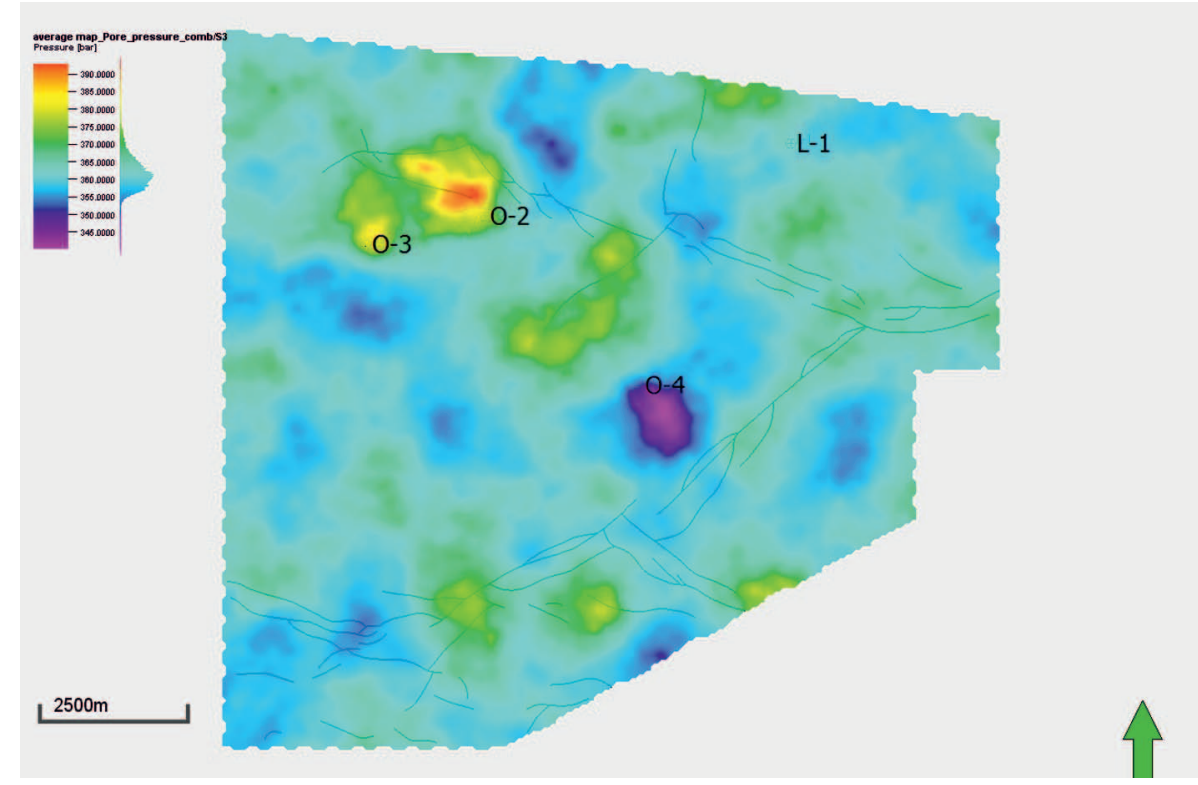

Rys. 6. Mapa wartości średnich ciśnienia porowego w jednym z interwałów perspektywnych Source 3 na tle przebiegu nieciągłości

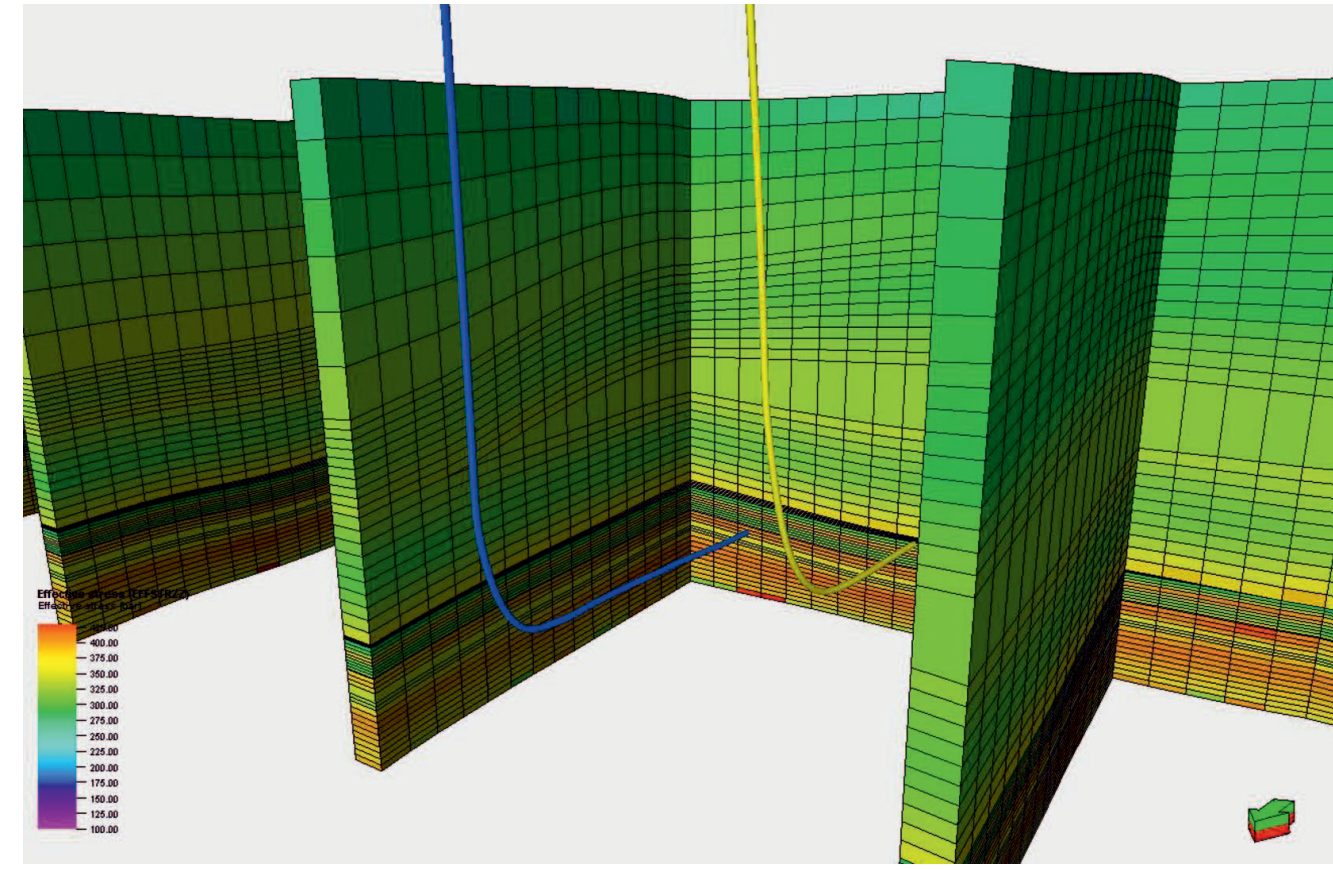

Rys. 7. Rozkład przestrzenny efektywnego naprężenia litostatycznego, w którego profilu obserwowany jest efekt występowania strefy podniesionego ciśnienia porowego 


\section{Wnioski}

1. W utworach o niskiej przepuszczalności ciśnienie porowe, z uwagi na brak możliwości przeprowadzenia pomiaru w odwiercie, jest szacowane metodami wykorzystującymi redukcyjny wpływ efektywnego naprężenia pionowego na porowatość osadów.

2. Obliczone profile czy przestrzenny model ciśnień porowych znajdują zastosowanie w modelowaniu geomechanicznym 1D i 3D, stanowiąc podstawę do obliczenia podstawowych naprężeń efektywnych.

3. Znajomość ciśnienia porowego formacji skalnych i jego zmiana wraz z postępem wiercenia odgrywa kluczową rolę w utrzymaniu stabilnej ściany odwiertu podczas wiercenia. Wskazane poziomy o podniesionym ciśnieniu porowym mogą stanowić cenną informację przy projektowaniu parametrów wiercenia kolejnych odwiertów w obrębie analizowanego obiektu.

4. W ramach ewentualnego kontynuowania tematyki na wybranym obiekcie O-3D wskazane wydaje się wykorzystanie danych sejsmicznych jako nośnika informacji o przestrzennym rozkładzie litofacji czy istnieniu bariery strukturalnej dla poziomego przepływu płynów w przestrzeni porowej.

Podziękowania: Autorka dziękuje firmie Schlumberger za udostępnienie specjalistycznego oprogramowania.

Prosimy cytować jako: Nafta-Gaz 2017, nr 4, s. 219-226, DOI: 10.18668/NG.2017.04.01

Artykuł nadesłano do Redakcji 29.11.2016 r. Zatwierdzono do druku 1.02.2017 r.

Artykuł powstał na podstawie pracy statutowej pt. Predykcja ciśnień porowych w otworach wiertniczych na potrzeby budowy modelu geomechanicznego dolnopaleozoicznych formacji skalnych - praca INiG - PIB na zlecenie MNiSW; nr zlecenia: 13/SG/16, nr archiwalny: DK-4100-/0013/2016.

\section{Literatura}

[1] Aldred W., Bergt D., Rasmus J., Voisin B.: Real-Time Overpressure Detection. Oilfield Review 1989, vol. 1, no. 3, s. 17-27.

[2] Boer L., Sayers C., Nagy Z., Hooyman P. J., Woodward M. J.: Pore pressure prediction using well-conditioned seismic velocities. First Break 2006, vol. 24, no. 5, s. 43-49.

[3] Bourgoyne Jr. A. T., Millheim K. K., Chenevert M. E., Young Jr. F. S.: Applied Drilling Engineering. SPE Textbook Series, vol. 2, Society of Petroleum Engineers, 1986.

[4] Bowers G.: Pore pressure estimation from velocity data: accounting for overpressure mechanisms besides undercompaction. SPE Drill Complet 1995, vol. 10, no. 2, s. 89-95.

[5] Eaton B.: The effect of overburden stress on geopressure prediction from well logs. J. Pet. Technol. 1972, vol. 24, no. 8, s. 929-934.

[6] Herwanger J., Koutsabeloulis N.: Seismic Geomechanics: How to Build and Calibrate Geomechanical Models using 3D and 4D Seismic Data. EAGE Publications, 2011.

[7] Jędrzejowska-Tyczkowska H., Słota-Valim M.: Mechaniczny model Ziemi jako nowy i konieczny warunek sukcesu w poszukiwaniach i eksploatacji niekonwencjonalnych złóż węglowodorów. Nafta-Gaz 2012, nr 6, s. 329-340.

[8] Jędrzejowska-Tyczkowska H., Żukowska K., Misiarz P., Bartoń R., Żuławiński K.: Prognozowanie występowania stref anomalnie wysokich ciśnień górotworu na podstawie danych sejsmicznych. Nafta-Gaz 2000, nr 12, s. 689-706.

[9] Sayers C. M.: Geophysics Under Stress: Geomechanical Applications of Seismic and Borehole Acoustic Waves. Distinguished Instructor Short Course, Society of Exploration Geophysicists, 2010.

[10] Sayers C. M., Johnson G. M., Denyer G.: Predrill porepressure prediction using seismic data. Geophysics 2002, vol. 67 , no. 4, s. 1286-1292.

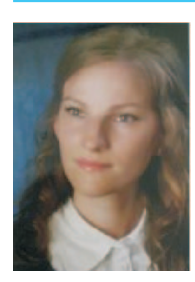

Mgr inż. Małgorzata SŁOTA-VALIM

Asystent w Zakładzie Geologii i Geochemii, Laboratorium Petrofizyki.

Instytut Nafty i Gazu - Państwowy Instytut Badawczy

ul. Lubicz 25 A

31-503 Kraków

E-mail:slota@inig.pl 